\title{
The Effect of Contextual Teaching and Learning Model Based on Ethnomathematics on the Students' Interest and Learning Outcomes of Class XII SMA Negeri 2 Salahutu in Three-Dimensional Materials
}

\author{
C Agustis ${ }^{1, *}$ W Mataheru² N C Huwaa ${ }^{3}$
}

\author{
1,2,3 Universitas Pattimura \\ Corresponding author. Email: agustis.christin@yahoo.com
}

\begin{abstract}
This study aims to determine the effect of Contextual Teaching and Learning (CTL) model based on ethnomathematics on the students' interest and learning outcomes of class XII SMA Negeri 2 Salahutu in three-dimensional materials. This study used experimental research with Quasi Experimental as the research design. The population in this study were all students of class XII MIA SMA Negeri 2 Salahutu totaling 30 people, this population was also used as research sample using saturation sampling. The instruments used in this study were questionnaires and test questions. The data analysis technique used was the Independent Sample T-Test. The results of the study indicate that there is an effect of CTL learning model based on ethnomathematics on students' interest and learning outcomes of class XII SMA Negeri 2 Salahutu in three-dimensional materials indicated by differences in student interest and learning outcomes in the experimental class and the control class with a significance value obtained at 0,016<0,05 and 0,036<0,05.
\end{abstract}

Keywords: Contextual Teaching and Learning, Ethnomathematics.

\section{INTRODUCTION}

Mathematics is a basic science that has a fundamental role in human life. Yet today, advances in science and technology develops fast and cannot be separated from the role of mathematics. It can be said that mathematics is the main foundation of science and technology [1]. Thus, a good mastery of mathematics is indispensable for progress in this country.

Although mathematics plays an important role in our lives, the students' interest in mathematics is still so low, this is signified by the lack of students' attention and participation during the learning process. Students have lower interest in mathematics because of the assumptions that mathematics is an abstract science, filled with numbers and formulas. Based [2], the perception of mathematics is a scary subject often exists among the children. This low interest in learning mathematics may result in low learning outcomes.

The mathematics learning outcomes of Indonesian students are considered to be low, as can be seen from the result of Programme for International Student Assessment (PISA) which states that Indonesian students' ability in mathematics are ranked 69 out of 76 participating countries [3]. The ranking is still below other countries in Southeast Asia such as Singapore, Malaysia dan Thailand. The results of Trends in International Mathematics and Science Study (TIMSS) also indicates that Indonesian students' mastery of mathematics are ranked 38 out of 42 countries with an average score of 386 , with the scale centerpoint of 500 [4]. This result also in line with observations conducted by researcher that the students' mathematics abilities of class XII MIA SMA Negeri 2 Salahutu are quite low. Of the total samples of 30 students, there were 19 students who had not reached the school KKM on the prerequisite test. Moreover, from the initial observations conducted by the researcher, it was found that the students tended to be passive and busy themselves during the mathematics learning process.

The low level of students' understanding in mathematics is not solely the result of the students' lack of ability, but the root of the problem may also come from the teachers, which is related to the use of inappropriate learning models [5]. Commonly, teachers tend to use monotonous learning models. One of the characteristics 
of educational practice in Indonesia so far is teachercentered learning. The teacher delivers the material using the lecture or expository method, the students only record what they hear in their notebook. This makes students become passive learners and tend to memorize the materials given. Even though the knowledge gained from memorization is less meaningful does not retain in students' long-term memories, the math concepts should not be memorized but understood properly.

One of the learning models that can increase the students' activities is Contextual Teaching and Learning (CTL) model based ethnomathematics. According to [6], CTL is a learning model that emphasizes students' active engagement to be able to find the material being studied and relate it to real-life situations so as to encourage students to apply it in their lives, while ethnomathematics is mathematics that grows and develops in particular societies [7]. Thus, if CTL is combined with ethnomathematics students will become more active in discovering the material being learned, so that learning becomes more meaningful, as well as abstract math concepts especially three dimensions that students can only imagine can become more real through association with their culture as shown in the following pictures.

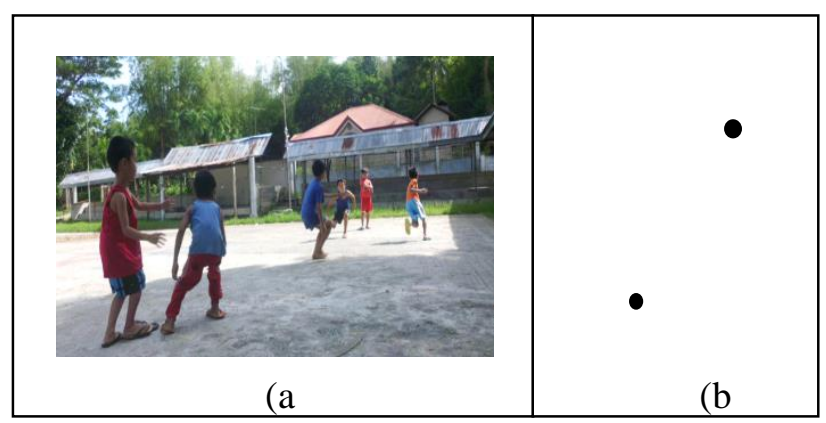

Figure 1 Two Stones in the Bentengan (Enemy Fort) Game (a) and Its Illustration (b).

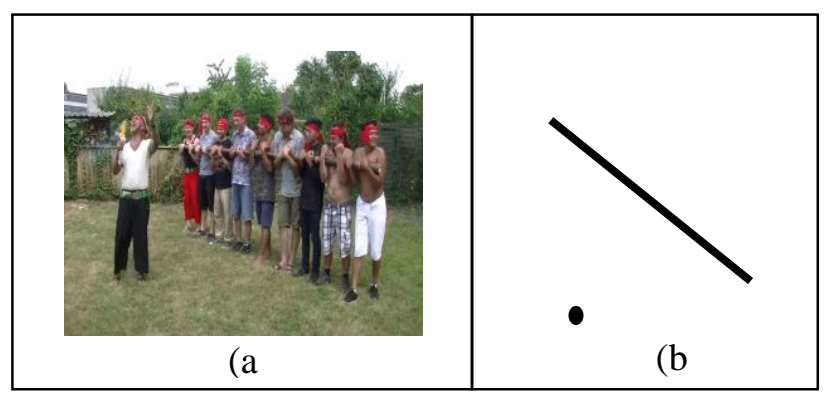

Figure 2 Bambu Gila (Crazy Bamboo Dance) (a) and Its Illustration (b).

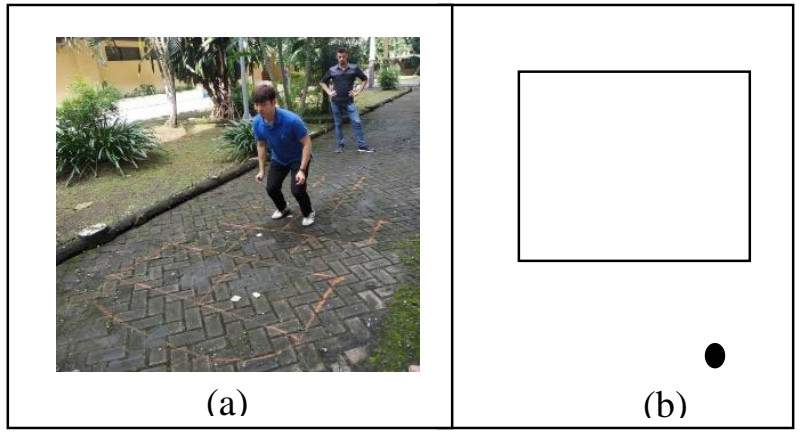

Figure 3 Box and Gaco in Gici-gici Game (a) and Its Illustration (b).

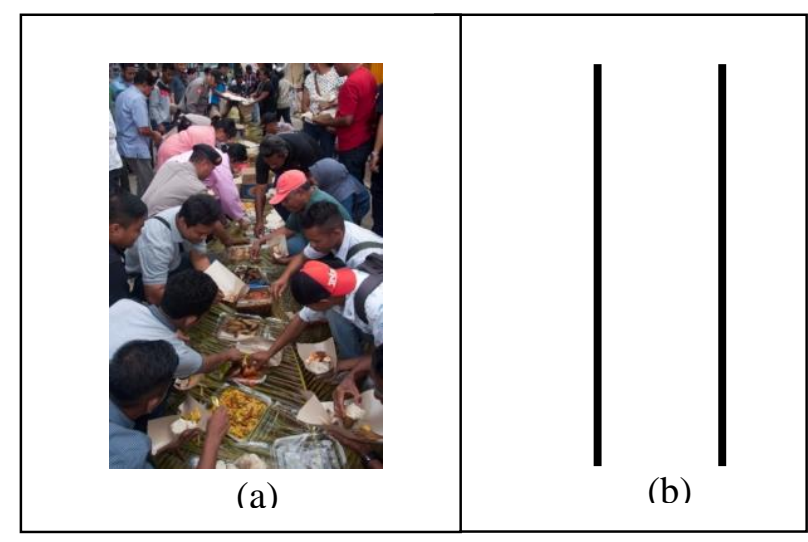

Figure 4 How People Sitting at Patita Eating Tradition (a) and Its Illustration (b).

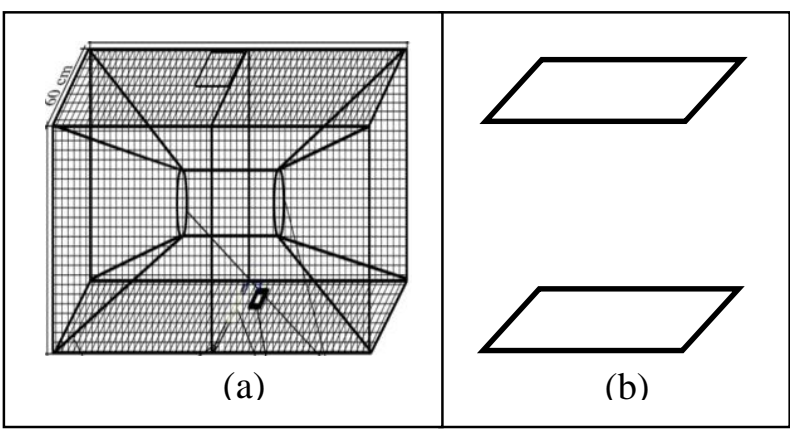

Figure 5 Top and Bottom Side of the Bubu (a) and Its Illustration (b).

In addition, CTL based on ethnomathematics bring new nuances in mathematics learning because it presents students' cultural background, which so far learning mathematics tends to be far from the everyday life context let alone the students' culture. This of course can have an impact on increasing students' attention and participation in the learning process. The 2013 national curriculum requires cultural engagement in each learning activity, so that CTL based on ethnomathematics becomes a suitable combination as a learning model.

Based on the description above, the study aims to determine the effect of CTL model based on Ethnomathematics on the students' interests and learning outcomes of class XII SMA Negeri 2 Salahutu in threedimensional materials. 


\section{METHOD}

This study used experimental research with Quasi Experimental Design. The research design used was Nonequivalent Posttest-Only Control Group Design. The population in this study were all students of class XII MIA SMA Negeri 2 Salahutu for the 2019/2020 academic year which consisted of two classes, namely XII MIA1 and XII MIA2. The samples in this study, namely class XII MIA1 as an experimental class using the Contextual Teaching and Learning (CTL) model based on ethnomathematics and class XII MIA2 as the control class using traditional learning models. The instruments used in this study were questionnaires and test items. The data collection technique used were questionnaires and tests. The data analysis technique included prerequisite tests and hypothesis testing.

\section{RESULT AND DISCUSSION}

\subsection{Research Results}

The results of this research consisted of the prerequisite test results and hypothesis testing.

\subsubsection{Prerequisite Test}

The prerequisite test consists of normality test and homogeneity test was conducted to determine of the research data are normally distributed and has a homogeneous variance or not. This tests was conducted with help of the SPSS 23.0 program for windows.

Table 1 The Results of Normality Test on Students' Learning Interest

\begin{tabular}{rcccc}
\hline \multirow{2}{*}{ Class } & \multicolumn{3}{c}{ Shapiro-Wilk } \\
\cline { 3 - 5 } & & Statistic & $\mathrm{df}$ & Sig. \\
\hline $\begin{array}{c}\text { Learning } \\
\text { Interest }\end{array}$ & $\begin{array}{c}\text { Class } \\
\text { Control Class }\end{array}$ & .978 & 16 & .942 \\
\hline
\end{tabular}

Table 1 show the results of Shapiro-Wilk test, it can be seen that the normality test results for the control class show a significance value of 0.591 and the experimental class shows a significance value of 0.942 . Based on the criteria in the normality test, it shows that $0.591>0.05$ and $0.942>0.05$, so from these results it can be concluded that the two questionnaire values of students' learning interest are normally distributed.

Table 2 The Results of Normality Test on Students' Learning Outcomes

\begin{tabular}{|c|c|c|c|c|}
\hline \multicolumn{2}{|c|}{ Class } & \multicolumn{3}{|c|}{ Shapiro-Wilk } \\
\hline & & Statistic & df & Sig. \\
\hline Learning & $\begin{array}{c}\text { Experimental } \\
\text { Class }\end{array}$ & .945 & 16 & .419 \\
\hline Outcomes & Control Class & .924 & 14 & .249 \\
\hline
\end{tabular}

From the results of Shapiro-Wilk test in table 2, it can be seen that the normality test results for the control class show a significance value of 0.249 and the experimental class shows a significance value of 0.419 . Based on the criteria in the normality test, it shows that $0.249>0.05$ and $0.419>0.05$, so from these results it can be concluded that the two test scores on students' learning outcomes are normally distributed.

Table 3 The Homogeneity Test Results on Students' Learning Interest

\begin{tabular}{cccccc}
\hline & & $\begin{array}{c}\text { Levene } \\
\text { Statistic }\end{array}$ & df1 & df2 & Sig. \\
\hline Learning & Based on Mean & 1.435 & 1 & 28 & .241 \\
$\begin{array}{c}\text { Interest } \\
\text { Based on Median }\end{array}$ & 1.381 & 1 & 28 & .250 \\
& $\begin{array}{c}\text { Based on Median and } \\
\text { with adjusted df } \\
\text { Based on trimmed } \\
\text { mean }\end{array}$ & 1.381 & 1 & 27.988 & .250 \\
\hline
\end{tabular}

From the table above, it can be seen that the results of the homogeneity test on students' learning interest in the control class and the experimental class are 0.241. Based on the criteria in the homogeneity test that is $0.241>$ 0.05 , it can be concluded that the two classes are homogeneous. 
Table 4 The Homogeneity Test Results on Students' Learning Outcomes

\begin{tabular}{cccccc}
\hline & & $\begin{array}{l}\text { Levene } \\
\text { Statistic }\end{array}$ & df1 & df2 & Sig. \\
\hline & Based on Mean & .243 & 1 & 28 & .626 \\
Learning & $\begin{array}{c}\text { Based on Median } \\
\text { Outcomes }\end{array}$ & .196 & 1 & 28 & .661 \\
& $\begin{array}{c}\text { Based on Median and } \\
\text { with adjusted df } \\
\text { Based on trimmed } \\
\text { mean }\end{array}$ & .196 & 1 & 27.127 & .661 \\
\hline
\end{tabular}

From table 4 above, it can be seen that the results of the homogeneity test on students' learning outcomes in the control class and experimental class are 0.626. Based on the criteria in the homogeneity test that is $0.626>$ 0.05 , it can be concluded that the two classes are homogeneous.

\subsubsection{Hypothesis Testing}

Table 5 The First Results of Hypothesis Testing
Hypothesis test consists by the first and second, were conducted to determine the differences of interests and learning outcomes of students of class XII SMA Negeri 2 Salahutu are taught with CTL learning model based on ethnomathematics and conventional learning models on three-dimensional materials or not. This testing of hypothesis using Independent Sample T-Test with help of the SPSS 23.0 program for windows.

\begin{tabular}{|c|c|c|c|c|c|c|c|c|}
\hline & & \multicolumn{7}{|c|}{ t-test for Equality of Means } \\
\hline & & \multirow[t]{2}{*}{$\mathrm{t}$} & \multirow[t]{2}{*}{ df } & \multirow{2}{*}{$\begin{array}{l}\text { Sig. (2- } \\
\text { tailed) }\end{array}$} & \multirow{2}{*}{$\begin{array}{c}\text { Means } \\
\text { Difference }\end{array}$} & \multirow{2}{*}{$\begin{array}{l}\text { Std. Error } \\
\text { Difference }\end{array}$} & \multicolumn{2}{|c|}{$\begin{array}{l}\text { 95\% Confidence } \\
\text { Interval of the } \\
\text { Difference }\end{array}$} \\
\hline & & & & & & & Lower & Upper \\
\hline \multirow{2}{*}{$\begin{array}{c}\text { Learning } \\
\text { Interest }\end{array}$} & $\begin{array}{l}\text { Equal variances } \\
\text { assumed }\end{array}$ & 2.561 & 28 & .016 & 5.56250 & 2.17216 & 1.11303 & 10.01197 \\
\hline & not assumed & 2.528 & 25.343 & .018 & 5.56250 & 2.20056 & 1.03347 & 10.09153 \\
\hline
\end{tabular}

From the results of the Independent Sample T-Test in table 5 above, it can be seen that the significance value is 0.016. Based on the criteria in the Independent Sample T-Test, it shows that $0.016<0.05$, so that $\mathrm{H} 0$ is rejected and $\mathrm{H} 1$ is accepted, which means that there is A difference in the average of students' interest in the control class and the experimental class. So, because there is a difference in learning interest between these two classes, it can be concluded that there is an effect of CTL learning model based on ethnomathematics on the students' learning interest of class XII SMA Negeri 2 Salahutu in three-dimensional materials.

Table 6 The Second Results of Hypothesis Testing

t-test for Equality of Means

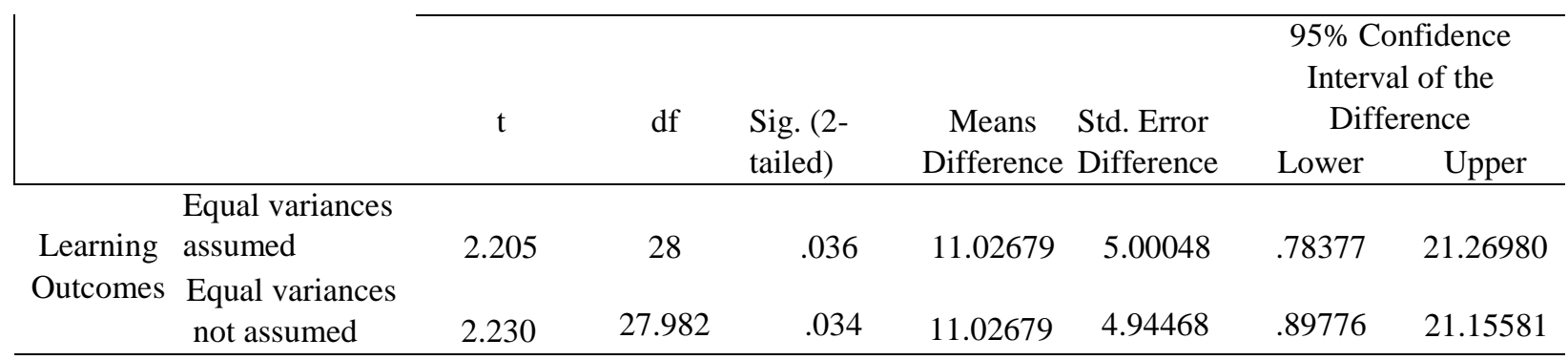

From the results of the Independent Sample T-Test in table 6, it can be seen that the significance value is 0.036 . Based on the criteria in the Independent Sample T-Test, it shows that $0.036<0.05$, so that $\mathrm{H} 0$ is rejected and $\mathrm{H} 1$ is accepted, which means there is a difference in the average of students' learning outcomes in the control 
class and the experimental class. So, because there are differences in learning outcomes between these two classes, it can be concluded that there is an effect of CTL learning model based on ethnomathematics on the students' learning outcomes of class XII SMA Negeri 2 Salahutu in three-dimensional materials.

\subsection{Discussion}

From the results of the research previously described, it showed that there is an effect of Contextual Teaching and Learning (CTL) model based on ethnomathematics on the students' interest and learning outcomes of class XII SMA Negeri 2 Salahutu in three- dimensional materials. The results of this study are also reinforced by the existence of research results that are in line with research by [8] and [9], which each show that CTL can foster students' learning interest because students understand the meaning of the material being studied because learning associates the material with real-life situations which students face in everyday life and ethnomathematics can be applied as a means to motivate, stimulate students, to overcome boredom and difficulties in learning mathematics. Other similar researches were conducted by [10] and [11], each of which showed that learning with CTL model makes students easier to understand the concepts being taught and the knowledge gained is long-term, and ethnomathematics can facilitate students to be able to construct math concepts with the initial knowledge they already know through their own environment.

\section{CONCLUSION}

There is an effect of Contextual Teaching and Learning (CTL) model based on ethnomathematics on the students' interest and learning outcomes of class XII SMA Negeri 2 Salahutu in three-dimensional materials.

\section{REFERENCES}

[1] T. H. Harahap, "Penerapan Contextual Teaching And Learning Untuk Meningkatkan Kemampuan Koneksi dan Representasi Matematika Siswa Kelas VII-2 SMP Nurhasanah Medan Tahun Pelajaran 2012/2013,” J. Chem. Inf. Model., vol. 53, no. 9, pp. 1689-1699, 2015.

[2] S. M. Patahuddin and A. F. Rokhim, "Website Permainan Matematika Online Untuk Belajar Matematika Secara Menyenangkan," J. Pendidik. Mat., vol. 3, no. 2, 2013, doi: 10.22342/jpm.3.2.332.

[3] I. Amelia, S. Syamsuri, and N. Novaliyosi, "Identifikasi Proses Penyelesaian Soal Literasi Matematika Siswa Kelas IX Pada Konten Peluang dan Data," J. Cendekia J. Pendidik. Mat., vol. 4, no. 1, pp. 331-345, 2020, doi: 10.31004/cendekia.v4i2.212.
[4] A. Pribadi, Somakim, and M. Yusup, "Pengembangan Soal Penalaran Model Timss Pada," Histogram J. Pendidik. Mat., vol. 1, no. 2, pp. 115-128, 2017.

[5] E. T. Wahyuni, "Pembelajaran Berbasis Masalah Untuk Meningkatkan Kemampuan Pemecahan Masalah Matematis Siswa Smk," Symmetry Pas. J. Res. Math. Learn. Educ., pp. 41-62, 2017, doi: 10.23969/symmetry.v1i1.208.

[6] W. Sanjaya, Strategi Pembelajaran Berorientasi Standar Proses Pendidikan. Jakarta: Kencana Prenada Media Group, 2011.

[7] theresia laurens, "Analisis Etnomatematika Dan Penerapannya Dalam Meningkatkan Kualitas Pembelajaran,” J. LEMMA, vol. 3, no. 1, pp. 86-96, 2017, doi: 10.22202/j1.2016.v1i3.1120.

[8] D. S. Setiana, "Jurnal Pendidikan Surya Edukasi (JPSE), Volume: 3, Nomor: 1, Juni 2017," J. Pendidik. Surya Edukasi, vol. 3, pp. 66-74, 2017.

[9] F. S. Sirate, "Implementasi Etnomatematika Dalam Pembelajaran Matematika Pada Jenjang Pendidikan Sekolah Dasar," Lentera Pendidik. J. Ilmu Tarb. dan Kegur., vol. 15, no. 1, pp. 41-54, 2012, doi: 10.24252/lp.2012v15n1a4.

[10] I. Awanda, R. Rochmiyati, and S. Sugiyanto, "Pengaruh Model Contextual Teaching And Learning Dengan Media Video Terhadap Hasil Belajar,” J. Pedagog., 2018.

[11] R. Richardo, "Peran Ethnomatematika Dalam Penerapan Pembelajaran Matematika Pada Kurikulum 2013," LITERASI (Jurnal Ilmu Pendidikan), vol. 7, no. 2, p. 118, 2017, doi: 10.21927/literasi.2016.7(2).118-125. 